Article

\title{
Towards Understanding Interactions between Sustainable Development Goals: The Role of Climate-Well-Being Linkages. Experiences of EU Countries
}

\author{
Agnieszka Sompolska-Rzechuła ${ }^{1}$ (D) and Agnieszka Kurdyś-Kujawska ${ }^{2, *(D)}$ \\ 1 Faculty of Economics, Department of Applied Mathematics in Economics, West Pomerania University of \\ Technology Szczecin, Janickiego 31, 71-270 Szczecin, Poland; asompolska@zut.edu.pl \\ 2 Faculty of Economics, Department of Finance, Koszalin University of Technology, Kwiatkowskiego 6e, \\ 75-343 Koszalin, Poland \\ * Correspondence: agnieszka.kurdys-kujawska@tu.koszalin.pl; Tel.: +48-94-3439-160
}

Citation: Sompolska-Rzechuła, A.; Kurdyś-Kujawska, A. Towards

Understanding Interactions between Sustainable Development Goals: The Role of Climate-Well-Being Linkages. Experiences of EU Countries. Energies 2021, 14, 2025. https://doi.org/ $10.3390 /$ en14072025

Academic Editor: Sergio Ulgiati

Received: 1 March 2021

Accepted: 4 April 2021

Published: 6 April 2021

Publisher's Note: MDPI stays neutral with regard to jurisdictional claims in published maps and institutional affiliations.

Copyright: (c) 2021 by the authors. Licensee MDPI, Basel, Switzerland. This article is an open access article distributed under the terms and conditions of the Creative Commons Attribution (CC BY) license (https:// creativecommons.org/licenses/by/ $4.0 /)$.

\begin{abstract}
The 2030 Agenda with 17 Sustainable Development Goals (SDGs) is a challenge for all countries in the world. Their implementation may turn out to be a compromise or the creation of effective interactions that dynamize sustainable development. To achieve the SDGs, it is essential to understand how they interact with each other. It seems that in the times of the climate and health crisis caused by the COVID-19 pandemic, caring for the environment and ensuring a healthy life and promoting well-being at all ages is the basis for environmental, economic and social sustainable development. The aim of the study is to compare the degree of implementation of the goals of sustainable development in the scope of goal 13 "Climate action" and goal 3 "Good health and well-being" in the EU countries. In addition, we analyze how trade-offs and synergies between these goals have developed. Data from the Eurostat database were used to achieve the goal. The study used the method of multivariate comparative analysis-linear ordering of objects. The technique for order preference by similarity to an ideal solution (TOPSIS) method was used to measure the studied phenomenon. The results indicate a different degree of implementation of the sustainable development goals related to climate change and the improvement of health and social well-being. Only a few countries have synergy in achieving these goals, most of them compromise, manifesting themselves in improving one goal over another. In the group of analyzed EU countries, a simultaneous deterioration in the effectiveness of achieving both objectives were also noted. Our research also shows that energy policy is an important attribute in improving the achievement of these goals. The conducted analysis fills the gap in the research on the implementation of selected sustainable development goals and their interactions. It contributes to the discussion on increasing the links between them, in particular with regard to emerging compromises. This research can provide a basis for re-prioritizing and intensifying the actions where individual EU countries are lagging most behind.
\end{abstract}

Keywords: sustainable development; climate; well-being; energy policy; COVID-19; linear ordering of objects; EU member states

\section{Introduction}

The 2030 Agenda for Sustainable Development, which includes the 17 Sustainable Development Goals (SDGs) and 169 related goals [1] that UN member states have committed to achieving by 2030, is a global roadmap for people, planet and welfare. The aim of this initiative is to promote sustainable development and improve the quality of life by protecting the natural environment, promoting low-carbon development and adapting to global environmental changes, especially climate change [2]. The implementation of the Agenda will largely depend on the ability of individual countries to maximize synergies 
and resolve existing trade-offs between the objectives or group of objectives [3]. The simultaneous implementation of two or more SDGs can potentially save resources for achieving the SDGs by harmonizing, coordinating or pooling efforts to achieve different SDGs [4].

As the problem of climate change becomes more complex and its essence as a global public good is enhanced, climate change management has received unprecedented attention in recent years [5]. National and global public health associations, as well as those dedicated to climate change, have unanimously recognized that climate change is a state of emergency that threatens public health [6,7].

The 2030 Agenda, through goal 13 (SDG13), called for urgent environmental action to combat climate change and its consequences. All tasks included in this objective have a potential impact on the improvement of health and social well-being, mainly as a result of reducing air pollution, improving energy efficiency and increasing the quality of life [8]. The tasks performed under the SDG13, if not properly planned, may affect the deterioration of social welfare and, consequently, contribute to the reduction of the effectiveness of the implementation of all social goals of sustainable development, including tasks for health and well-being (SDG3) [9-11].

The presentation of this study is structured as follows: First, relevant literature on climate and well-being and their relevance to sustainable development is presented. Then, a research gap was identified in the studies on the degree of implementation of SDGs 3 and 13 and the links between them in the EU countries. Second, the set of indicators and the methodology used in the study are briefly presented. Then, in the third and fourth sections, we report the findings from the research and try to assess the relationship between the received orders of countries in terms of the implementation of SDGs 3 and 13, and we will indicate the relationships between these goals. In the last part, we present our main conclusions and recommendations.

\subsection{Climate and Wellbeing}

The threats resulting from the changing climate are multifaceted [12], they constitute an existential threat to many aspects of public life and the Earth's ecosystems $[13,14]$. Climate change affects poverty, health, the economy, infrastructure, equality and gender relations [15]. People and communities around the world are increasingly witnessing dramatic and chronic environmental degradation and are experiencing a number of related responses and impacts [16]. It is well known that the effects of climate change threaten human health [17-32], and also increase existing inequalities, making the most marginalized people more vulnerable to the health consequences of a changing climate [33].For example, Patz et al. [17] indicates that many common human diseases are associated with climate fluctuations, from cardiovascular mortality and respiratory disease caused by heat waves to increase transmission of infectious diseases and malnutrition due to crop failure. Onozuka et al. [23] by analyzing future prognosis of excessive sudden cardiac arrest in an out-of-hospital environment related to climate change, showed a relationship between global climate change and mortality. Alahmad et al. [24] showing the relationship between temperature extremes and mortality. They argue that extremely high temperatures increase the risk of death from cardiovascular causes. Tang et al. [25] are of the same opinion. They suggest that extreme temperatures may increase the risk of hospitalization for ischemic stroke - an acute cardiovascular disease with high levels of disability and mortality. Garcia and Sheehan [28] prove in turn that extreme weather events cause a significant burden of mortality and morbidity among children. Hrabok et al. [18] and Hayes et al. [34] prove that the effects of climate change affect mental health, including post-traumatic stress disorder, depression, suicide and anxiety. Bai et al. [22] proves that short-term exposure to high level of ambient particulate matters has been linked with increased hospital admissions for schizophrenia. Castello et al. [31] and Mc Michael et al. [32] proved that changes in climate cause an acute exacerbation of chronic respiratory diseases (including asthma and allergies) and an increase in the incidence of diseases transmitted by vectors, water and food. Hayes et al. [34] state that "climate change is a destructive reality with dire 
predictions for the future". The effects of a changing climate may exceed the ability of many countries and their public health support institutions to adapt effectively and may have a negative impact on health outcomes [35]. If doubts have emerged about the urgent need to strengthen public health and welfare efforts to prepare for the inevitable climate change, the COVID-19 pandemic has dispelled them [36]. The response of all countries around the world to COVID-19 in early 2020 revealed important gaps in adaptability [37]. The fact is that, to date, both public and private institutions in many countries have not acted quickly enough to prevent climate change. The emergence of COVID-19 shows how important it is to think long-term and incorporate it into strategies and risk management [38]. The pandemic has highlighted the importance of effective public health and healthcare systems and the importance of reducing poverty, reducing inequality, increasing universal health care, and promoting food and water security. Healthy populations and flexible health systems are critical to any country's quality of life, economic growth and development [39]. As underlined by Beccari [40] a community's ability to demonstrate adaptability or resilience to climate change depends on its technical, institutional, economic and cultural capacity, as well as on the existing healthcare infrastructure. There is currently no evidence that the coronavirus is linked to climate change, but McMichael [41] points out that global warming, which results in excessive greenhouse gas emissions, will support epidemic conditions for infectious diseases and enhance other health impacts related to heat, drought, storms and other threats. It has been proven, however, that the incidence of COVID-19 and the course of the disease is related to temperature, pollution level and particulate matter (PM) concentration in the air [42-51].For example, Coccia [42] shows through her research that the accelerated and widespread spread of COVID-19 in northern Italy was highly associated with measured urban air pollution. Yao [44] shows that PM pollution was positively associated with COVID-19. Long-term exposure to particulate matter pollution increased the susceptibility of the Chinese population to SARSA-COVID-2 and affected patient prognosis. Zoran et al. [46] by examining the relationship between atmospheric pollutants from the ground level, together with air quality and climate variables (average daily temperature, relative humidity, wind speed, atmospheric pressure and planetary boundary layer), prove that high levels of air pollution in cities, weather and specific conditions climate has a significant impact on the increased rates of confirmed total daily new and total deaths in Milan. Pramanik et al. [47], analyzing the influence of climatic and bio-climatic factors on the spread of COVID-19 in Russia, suggest that temperature, wind speed and humidity had an impact on the intensity of COVID-19 transmission. Similar conclusions were reached by Ahmadi et al. [51] examining climatological parameters to determine the COVID-19 outbreak in Iran, indicating that wind speeds, humidity and exposure to solar radiation were associated with a high infection rate, favoring the survival of the SARSA-COVID-2 virus. Coro [48] proves that a high COVID-19 infection rate is associated with CO 2 levels, as well as air temperature and rainfall (or air humidity).

\subsection{The Energy-Climate-Wellbeing}

Urgent and significant climate change mitigation will help protect human health from the worst of these impacts, and a comprehensive and ambitious response to climate change could change the state of global health [52]. Energy as a policy field is almost a classic crosscutting topic, closely related to climate, social and environmental policy [53,54]. It turns out that balancing the effects of climate change, sustainable development and environmental protection, as well as improving social welfare are becoming inextricably linked with energy production and supply [55]. As shown by the existing research results, improvement of energy efficiency, reduction of greenhouse gas emissions, dissemination of renewable energy, or access to clean energy are important indicators of climate change, health and social well-being [9,56-67]. These elements are interrelated and should be given priority [68]. As noted by Kettner et al. [58] individual countries are characterized by very specific energy systems (supplemented with specific social structures), which determines the challenges that each country must overcome on the path to decarbonization and sustainable develop- 
ment. Bhardwaj et al. [57] make it clear that energy systems, in addition to fuels, conversion technologies, distribution infrastructure and electronics, are part of wider chains linking systems to resources, natural cycles, and institutional and social solutions. This means that energy decisions have multiple non-energy implications in many aspects of society. Santika et al. [59] argue that energy is a key factor in achieving the SDGs, as energy plays a key role in eradicating poverty and hunger, providing healthcare, education and water, as well as maintaining economic growth and protecting the environment. Wang et al. [61] assessing and comparing the energy and environmental performance of selected countries, state that improving energy efficiency is of key importance for the climate. Moreover, it is a proven way to cost-effectively reduce greenhouse gas emissions, increase economic activity and improve resource productivity. On the other hand, Urban and Nordensvärd [62] proved that low-carbon energy transformation is important for mitigating climate change, reducing air pollution and reducing fossil fuel depletion. The transition to low carbon energy means the transition from a country's economic activity based on fossil fuels to an economy based (partly) on renewable and low carbon energy. This is by replacing fossil fuel-based technologies with low carbon technologies. Hajdukiewicz and Pera [63] emphasize that renewable energy, and in particular the development of the solar panel sector, plays a very important role in the aspect of energy security, ecology and climate change management. Similarly, Bertheau [60] believes that renewable energy technologies (solar energy and batteries) have significant potential not only in terms of improving sustainable development but also in terms of reliability while reducing energy costs.

The global climate system is now under pressure from increasing global average temperatures. Natural events and human activities are believed to contribute to global warming and climate change by enhancing the natural "greenhouse effect" [69]. This is mainly due to the increase in greenhouse gas (GHG) emissions such as carbon dioxide $\left(\mathrm{CO}_{2}\right)$, water vapors $\left(\mathrm{H}_{2} \mathrm{O}\right)$, methane $\left(\mathrm{CH}_{4}\right)$, chlorofluorocarbons (CFCs) etc. [70,71]. A planet warming up due to high concentrations of greenhouse gases leads to changes in the climate [72]. It is pointed out that the largest single source of greenhouse gas emissions in the world, producing an estimated $72 \%$ of all greenhouse gas emissions, is the combustion of fossil fuels $[73,74]$. $66 \%$ of these emissions come from the energy sector, from heat and electricity production [67]. A step towards a low-emission life brings health benefits that will improve the quality of life and reduce the effects of air pollution [75]. It is estimated that 300 to 700 million premature deaths could be avoided each year if the World Health Organization (WHO) minimum air cleanliness standards were applied in practice. According to WHO statistics, environmental conditions are responsible for a quarter of deaths due to respiratory diseases and other infectious diseases [76]. Unfortunately, 1.2 billion people worldwide do not have access to electricity, and 2.7 billion people depend on burning unsustainable and ineffective solid fuels [67]. A rapid transition to renewable energy as well as a mission-free replacement for fossil fuels would bring direct climate and health benefits now and minimize future health burdens $[77,78]$. Where renewable energy sources displace fossil fuels (especially coal), morbidity and mortality from air pollution are reduced $[67,79]$.

\subsection{Conceptual Framework}

The SDGs are conceived as an "indivisible whole" [80]. However, as the results of the research conducted so far show, the implementation of individual sustainable development goals may be based on synergy (progress in one goal favors progress in another) or compromise (progress in one goal hampers progress in another) [3,81,82]. The assessment of potential synergies and trade-offs between the SDGs is considered to be one of the most urgent research priorities for SDGs [83]. Omitting synergies and trade-offs in the assessment and planning processes related to the achievement of individual SDGs carries the risk of sub-optimal or even unfavorable results [84]. Although there are a number of studies in this field [80,81,83,85-103] covering different contexts, so far little attention has been paid to the links between actions taken to combat climate change and its impacts and 
actions to improve health and social well-being. Our research has the potential to help fill this important gap and increase our understanding of the interactions between these goals.

The implementation of the SDGs varies significantly from country to country due to various factors, including social, economic, environmental, and political and institutional. It should be emphasized, however, that it is largely the result of actions adopted by governments that favor the achievement of two or more goals of sustainable development at the same time [104]. Therefore, we believe that there is an urgent need for research to understand how individual EU countries perceive the Sustainable Development Goals, which call for urgent action to address climate change and to improve health and social well-being. Understanding the extent to which these objectives are being met and how they are related to each other is critical to the formulation of good policies and more effective actions and funding to support their implementation. One of the messages in this review is that the success of each of the two goals will largely depend on the other and on the ability of countries to develop and implement programs and actions to meet climate, health and social well-being goals in an integrated, coordinated and comprehensive manner [105]. It should be noted that the deadline for implementing the SDGs is about to expire. This research may constitute the basis for changing the priorities adopted so far and intensifying the actions for which individual EU countries lag the most. The aim of our research is to compare the degree of achievement of the sustainable development goals in the scope of goal 13 "Climate action" and goal 3 "Good health and well-being" in EU countries. In addition, we analyze how trade-offs and synergies between these goals have developed. Our choice of Sustainable Development Goals is motivated by the earlier findings that future health and social welfare will depend on action taken to tackle climate change and in particular on the implementation of an appropriate energy policy. We assumed that SDG3 is the overriding goal of sustainable development and the implementation of other goals, including SDG13, should lead to the achievement of a high level of SDG3 [106]. We believe that trying to describe and establish the statements in which progress in SDG13 implementation affects progress in SDG3 implementation may be particularly useful when combined with data collected systematically across countries to monitor progress towards SDGs. There is no doubt that actions in the field of climate change and the improvement of health and social well-being must be integrated in order to solve the greatest problems of the modern world in a holistic manner. To achieve the desired results, policy makers need to understand the feedback and interactions between climate and well-being. This will help them avoid unanticipated results when implementing their sustainable development initiatives.

\section{Materials and Methods}

\subsection{Materials}

In this article, we use a set of indicators that represent the two goals of SDG3 and SDG13 sustainability.

The following indicators were distinguished under SDG3 "Good health and wellbeing":

1. Life expectancy at birth by sex (years).

2. Share of people with good or very good perceived health by sex (\% of population aged 16 or over).

3. Smoking prevalence by sex (\% of population aged 15 or over).

4. Standardized death rate due to tuberculosis, HIV and hepatitis by type of disease number (per 100,000 persons).

5. Standardized preventable and treatable mortality number (per 100,000 persons aged less than 75 years).

6. Self-reported unmet need for medical examination and care by sex (\% of population aged 16 and over).

7. Obesity rate by body mass index (BMI) (\% of population aged 18 or over).

8. People killed in accidents at work, by sex (number per 100,000 employees). 
9. Population living in households considering that they suffer from noise, by poverty status (\% of population).

10. People killed in road accidents (per 100,000 persons).

11. Exposure to air pollution by particulate matter $\left(\mu \mathrm{g} / \mathrm{m}^{3}\right)$.

While SDG13“Climate action" includes indicators:

1. Greenhouse gas emissions (tons per capita).

2. Greenhouse gas emissions intensity of energy consumption (index $2000=100$ ).

3. Mean near-surface temperature deviation (degree Celsius).

4. Climate related economic losses by type of event-EU aggregate (million EUR and EUR per capita in current prices).

5. Contribution to the international 100bn USD commitment on climate related expending (million EUR in current prices).

6. Population covered by the Covenant of Mayors for Climate \& Energy signatories (\% of population).

7. Share of renewable energy in gross final energy consumption by sector (\%).

8. Average $\mathrm{CO}_{2}$ emissions per $\mathrm{km}$ from new passenger cars $\left(\mathrm{g} \mathrm{CO}_{2}\right.$ per $\left.\mathrm{km}\right)$.

9. Global mean ocean Surface acidity.

The information contained in the Eurostat database [107] for the years 2010 and 2018 for 28 European Union Member States was used to achieve the goal.

\subsection{Methods}

Linear ordering methods are used to evaluate multi-feature objects (e.g., countries) and allow them to be ranked, according to a specific general criterion, from "best" to "worst". This criterion is treated as a property of the examined objects and is a complex phenomenon. Socio-economic research very often examined phenomena that are not directly measured. Sets of diagnostic features are used then, measured on various measuring scales. Linear ordering of objects is obtained on the basis of a feature called aggregate or synthetic, which is created by aggregating the initial features describing the tested objects.

The synthetic feature creation procedure is a multi-step process and includes [108]:

- Selecting of simple features-important from the point of view of the studied phenomenon, measuring them for the tested objects and preparing a final list of features by removing features with low variability and features overly correlated with others;

- Determining the direction of preferences of simple features in relations to the general criterion under consideration and normalizing the values of variables for objects;

- Choosing the appropriate aggregation method and determining the value of a synthetic development measure for each object;

- Construction of the object ranking;

- Recognition of developmental types, substantive assessment and interpretation of obtained results.

The first step in creating a synthetic feature is to establish a set of diagnostic features. There are two approaches to this issue-non-statistical (substantive) and statistical [108]. The substantive approach is based on the qualitative assessment of the studied phenomenon, considering economic knowledge and theory. The statistical approach is designed to limit the set of diagnostic features and exclude those features that do not fully characterize the examined objects in terms of the adopted criterion. Analysis of variability and correlations between features is often used.

It is important that the features show adequate variability, i.e., they effectively discriminate against objects. The variation coefficient is used to assess the variability of the values of the features:

$$
v_{k}=\frac{s_{k}}{\bar{x}_{k}} \times 100 \%
$$

where: $\bar{x}_{k}$-arithmetic mean of the $k$-th feature, $s_{k}$-standard deviation of the $k$-th feature. 
The research eliminates those features for which the absolute value of the coefficient of variation is below a certain arbitrary threshold value. The most common value is $10 \%$.

Another condition that diagnostic features should meet is the lack of correlation between features. Therefore, from the set of potential features, features strongly correlated with others should be eliminated, because they are a carrier of similar information.

The set of diagnostic features is the basis for further analysis, in which the nature of the features should be determined, i.e., stimulants, destimulants and nominants should be distinguished. The stimulant is a feature in which higher values indicate a better condition of the object in a given context, while the destimulant is a feature in which lower values indicate a better situation of the object in a given respect. Nominations are the type of variables that are stimulants in one range of a variable and stimulants in another. Desirable (optimal) values should be defined for the nominants [109].After recognizing the nature of the features, they must be transformed; most often destimulants are converted into stimulants by means of differential or quotient transformations.

The next stage of building the synthetic feature is the normalization of features. It leads to deprivation of physical units of measurement results and unification of orders of magnitude. The literature contains many proposals for these methods and discussions on the criteria for their selection. The rest of the work will present those normalizing formulas that relate to stimulus traits.

The zero-unitization formula have been used in this work [110]:

$$
z_{i j}=\frac{x_{i k}-\min _{k} x_{i k}}{\max _{k} x_{i k}-\min _{k} x_{i k}}\left(\max _{k} x_{i k} \neq \min _{k} x_{i k}\right)
$$

where: $z_{i j}$-standardized value of the $j$-th feature for the $i$-th object; $\min _{l} x_{l j}$-minimum value of the $k$-th variable; $\max _{l} x_{l j}$-maximum value of the $k$-th variable; $k$-number of variable.

In the zero unitarization method, a constant reference point is assumed-the range of the normalized variable. The use of this method makes the range of the normalized feature constant and amounts to one. The normalized feature assumes values in the range 0-1. Moreover, this method makes it possible to normalize the features taking positive, negative and zero values.

To assess the degree of implementation of selected sustainable development goals in the European Union countries, the TOPSIS (Technique for Order Preference by Similarity to an Ideal Solution) position approach was used. The classic version of the TOPSIS method was developed by Hwang and Yoon [111] and is one of the best-known techniques for solving multi-criteria decision problems with a finite number of alternatives. The TOPSIS method and its modifications have found wide application in many issues [112-116], e.g., in supply chain management and logistics, business and marketing management, human resources management, energy management, water-resources management, environment [117].

The linear ordering method using the pattern and non-pattern is the TOPSIS method [111]. It consists in calculating the Euclidean distances of each assessed object from both the pattern and non-pattern of the development, which distinguishes it from the Hellwig method, which only considers the distance from the development pattern [108]. The coordinates of the model units are set-development pattern and non-pattern. The values of the pattern $\left(\mathrm{A}^{+}\right)$and non-pattern of development $\left(A^{-}\right)$are defined as $[108,109,118]$ :

$$
\begin{aligned}
& A^{+}=\left(\max _{i}\left(z_{i 1}\right), \max _{i}\left(z_{i 2}\right), \ldots, \max _{i}\left(z_{i k}\right)\right)=\left(z_{1}^{+}, z_{2}^{+}, \ldots, z_{k}^{+}\right) \\
& A^{-}=\left(\min _{i}\left(z_{i 1}\right), \min _{i}\left(z_{i 2}\right), \ldots, \min _{i}\left(z_{i k}\right),\right)=\left(z_{1}^{-}, z_{2}^{-}, \ldots, z_{k}^{-}\right)
\end{aligned}
$$


If zero unitarization is used as the normative formula, it is:

$$
z^{+}=\left(1, \underset{k}{1, \ldots, 1)} z^{-}=(0,0, \ldots, 0) .\right.
$$

Calculating the Euclidean distances of each object from the reference and anti-reference is made according to the formulas:

$$
d_{i}^{+}=\sqrt{\sum_{j=1}^{k}\left(z_{i j}-z_{j}^{+}\right)^{2}}, d_{i}^{-}=\sqrt{\sum_{j=1}^{k}\left(z_{i j}-z_{j}^{-}\right)^{2}} i=1, \ldots, n .
$$

While the value of the synthetic feature is determined as follows [115]:

$$
\mu_{i}=\frac{d_{i}^{-}}{d_{i}^{+}+d_{i}^{-}}
$$

wherein: $0 \leq \mu_{i} \leq 1, \quad i=1,2, \ldots, n$.

The smaller the distance of a given object from the development pattern, and thus greater than the development anti-reference, the closer the value of the synthetic feature.

\section{Results}

Taking into account the postulates that should be met by diagnostic variables, i.e., strong variability and weak correlation, as well as the availability of data in the Eurostat database for all surveyed countries in 2010 and 2018, the variables presented in Table 1

\begin{tabular}{|c|c|}
\hline \multicolumn{2}{|r|}{ SDG3 } \\
\hline$X_{2}$ & $\begin{array}{l}\text { Share of people with good or very good perceived health by sex ( } \% \text { of population } \\
\text { aged } 16 \text { or over). }\end{array}$ \\
\hline$X_{3}$ & Smoking prevalence by sex ( $\%$ of population aged 15 or over) \\
\hline$X_{6}$ & $\begin{array}{l}\text { Self-reported unmet need for medical examination and care by sex ( } \% \text { of population } \\
\text { aged } 16 \text { and over). }\end{array}$ \\
\hline$X_{8}$ & People killed in accidents at work, by sex (number per 100,000 employees). \\
\hline$X_{9}$ & $\begin{array}{l}\text { Population living in households considering that they suffer from noise, by poverty } \\
\text { status ( } \% \text { of population). }\end{array}$ \\
\hline \multicolumn{2}{|r|}{ SDG13 } \\
\hline$X_{1}$ & Greenhouse gas emissions (tons per capita). \\
\hline$X_{2}$ & Greenhouse gas emissions intensity of energy consumption (index $2000=100$ ). \\
\hline$X_{6}$ & $\begin{array}{l}\text { Population covered by the Covenant of Mayors for Climate \& Energy signatories } \\
\text { (\% of population). }\end{array}$ \\
\hline$X_{7}$ & Share of renewable energy in gross final energy consumption by sector $(\%)$. \\
\hline
\end{tabular}
were selected for the study.

Table 1. Set of variables accepted for the study.

The identified variables meet the above postulates, and are also expressed as indicators, therefore they can be used as the basis for comparisons of EU countries. Table 2 presents the values of the basic descriptive parameters in 2010 and 2018 for the indicators defined in goal 3. 
Table 2. Values of descriptive parameters in 2010 and 2018 regarding indicators defined in SDG3.

\begin{tabular}{|c|c|c|c|c|c|c|c|c|c|c|}
\hline \multirow{3}{*}{ Specification } & \multicolumn{10}{|c|}{ Variables } \\
\hline & \multicolumn{2}{|c|}{$X_{2}$} & \multicolumn{2}{|c|}{$X_{3}$} & \multicolumn{2}{|c|}{$X_{6}$} & \multicolumn{2}{|c|}{$X_{8}$} & \multicolumn{2}{|c|}{$X_{9}$} \\
\hline & 2010 & 2018 & 2010 & 2018 & 2010 & 2018 & 2010 & 2018 & 2010 & 2018 \\
\hline Mean & 66.03 & 67.08 & 29.57 & 25.71 & 3.49 & 2.75 & 2.62 & 1.87 & 18.57 & 16.44 \\
\hline Median & 67.50 & 68.90 & 30.00 & 26.50 & 1.90 & 1.85 & 2.47 & 1.93 & 18.35 & 17.00 \\
\hline Max & 83.30 & 84.10 & 42.00 & 37.00 & 15.10 & 16.40 & 4.93 & 4.49 & 31.60 & 28.20 \\
\hline Min & 47.70 & 44.00 & 21.00 & 7.00 & 0.10 & 0.10 & 0.62 & 0.45 & 9.50 & 8.00 \\
\hline St. Dev. & 10.15 & 9.83 & 5.79 & 6.67 & 3.75 & 3.39 & 1.23 & 0.96 & 5.65 & 5.68 \\
\hline Variation coefficient & 15.37 & 14.65 & 19.60 & 25.94 & 107.70 & 123.12 & 46.74 & 51.31 & 30.45 & 34.56 \\
\hline Skewness & -0.40 & -0.86 & 0.02 & -0.52 & 1.69 & 2.75 & 0.23 & 0.60 & 0.51 & 0.45 \\
\hline
\end{tabular}

All variables are characterized by strong or very strong volatility. The distributions of most of the variables show a strong right-hand asymmetry. The distribution of one variable $-X_{6}$ in both analyzed years is characterized by a very strong right-hand asymmetry. Right-hand asymmetry means that in most of the studied EU countries, higher values of the variables were observed compared to their arithmetic means. The exception is the variable $X_{2}$ in both examined years, which is asymmetric in the left-hand direction. This means that the percentage of people in good or very good health in most of the countries surveyed was higher than the average percentage. A total of $84.1 \%$ of the Irish population declared good or very good health-the highest percentage among the countries surveyed. On the other hand, Lithuania had the lowest percentage of the population (44\%) of variable $X_{2}$. In 2018, an increase in the asymmetry strength of the $X_{2}$ variable was observed. In the case of the distribution of the $X_{3}$ variable, i.e., the percentage of the population aged 15 and over, who reported smoking cigarettes, cigars, cigarillos or pipes during direct home interviews, a change in the direction of asymmetry from the right-hand side in 2010 to the left-hand side in 2018 was observed. In 2010, in most of the countries surveyed, the percentage of people declaring smoking was lower than the average percentage, and in 2018-higher. In 2018, the average percentage of smokers and the values relating to the minimum and maximum value of the $X_{3}$ variable decreased (e.g., in Sweden the percentage of smoking decreased from $26 \%$ in 2010 to $7 \%$ in 2018, while only three countries saw an increase percentage, e.g., in the Czech Republic, an increase by 3 pp was recorded from $26 \%$ to $29 \%$. Table 3 presents the values of the basic descriptive parameters in 2010 and 2018 concerning the indicators defined in goal 13.A comparative visualization of the distribution of the values of features related to SDG13 is presented in Figure 1.

Table 3. Values of descriptive parameters in 2010 and 2018 regarding indicators defined in SDG13.

\begin{tabular}{|c|c|c|c|c|c|c|c|c|}
\hline \multirow{3}{*}{ Specification } & \multicolumn{8}{|c|}{ Variables } \\
\hline & \multicolumn{2}{|c|}{$X_{1}$} & \multicolumn{2}{|c|}{$X_{2}$} & \multicolumn{2}{|c|}{$X_{6}$} & \multicolumn{2}{|c|}{$X_{7}$} \\
\hline & 2010 & 2018 & 2010 & 2018 & 2010 & 2018 & 2010 & 2018 \\
\hline Mean & 10.19 & 9.23 & 94.99 & 83.91 & 18.99 & 42.12 & 15.92 & 21.07 \\
\hline Median & 9.50 & 8.40 & 92.60 & 84.20 & 20.30 & 42.30 & 12.88 & 17.32 \\
\hline Max & 25.50 & 20.30 & 124.90 & 102.80 & 44.20 & 91.50 & 46.96 & 54.65 \\
\hline Min & 5.80 & 5.40 & 83.40 & 57.60 & 0.02 & 3.80 & 0.98 & 7.39 \\
\hline St. Dev. & 3.98 & 3.31 & 9.47 & 9.37 & 11.57 & 19.97 & 10.92 & 11.80 \\
\hline Variation coefficient & 39.05 & 35.83 & 9.97 & 11.17 & 60.97 & 47.41 & 68.63 & 56.01 \\
\hline Skewness & 2.20 & 1.59 & 1.67 & -0.71 & -0.02 & 0.30 & 0.93 & 1.13 \\
\hline
\end{tabular}




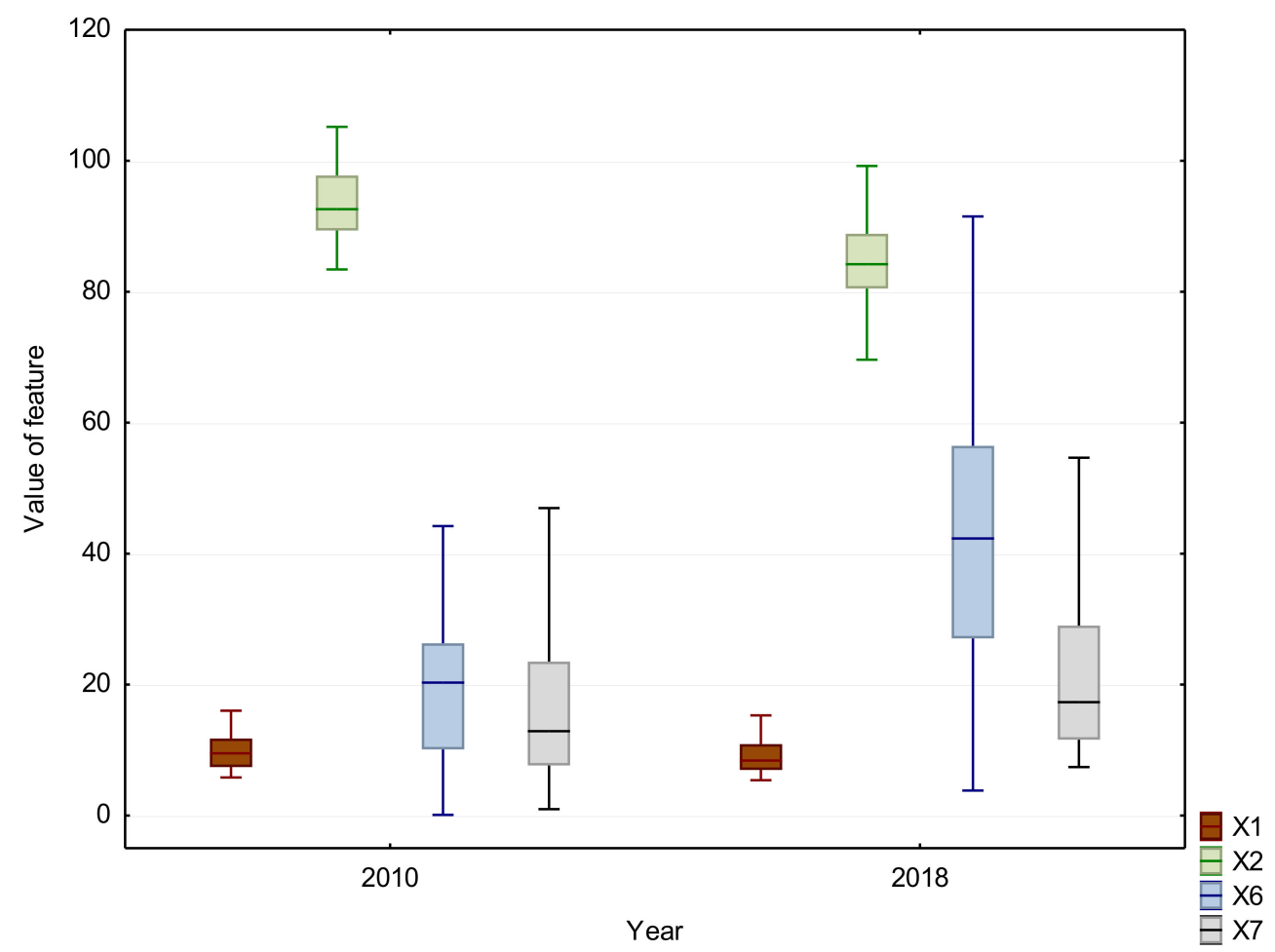

Figure 1. Distribution of the value of features for SDG13.

In the case of the variables related to the achievement of goal 13 related to Climate action, their strong or very strong variability was observed. The variable $X_{2}$ is characterized by the weakest variability (approx. 10\%), and the variable $X_{7}$-the strongest (from $56 \%$ to approx. $67 \%)$. Two of the variables $\left(X_{1}\right.$ and $\left.X_{7}\right)$ show a very strong right-hand asymmetry in each of the examined years. The distribution of the $X_{6}$ variable defining the percentage of the population covered by the signatories of the Covenant of Mayors for climate and energy in the year showed a very weak left-hand asymmetry, while in 2018 both the direction and strength of the asymmetry changed-to a moderately strong right-hand direction. The average percentage of the population covered by the Agreement increased significantly from 19\% to $42 \%$ in 2018 (e.g., in the case of Belgium, the tested variable increased its value from $19.3 \%$ in 2010 to $91.5 \%$ in 2018). In 2018, there was a decrease in the average value of variable $X_{2}$ compared to the value in 2010 . However, in some countries, greenhouse gas emissions still increase (e.g., in Lithuania in 2018 there was an increase in emissions by $2.8 \mathrm{pp}$ compared to the emissions in 2010). The largest decrease in greenhouse gas emissions was recorded in Malta—42.4 pp compared to emissions in 2010 and in Denmark - by 32.8 pp. A favorable change was also noted in relation to $X_{7}$ - the average share of renewable energy in final energy consumption increased by $5.1 \mathrm{pp}$. The highest percentage was recorded in Sweden both in 2010 (46.96\%) and in 2018 (54.65\%). Additionally, in another Scandinavian country, Finland has seen an increase in the share of renewable energy in final energy consumption, from $32.44 \%$ in 2010 to $41.16 \%$ eight years later. The largest increase in the share of renewable energy in final energy consumption was recorded in Denmark-by 13.82 pp from $32.44 \%$ in 2010 to $35.71 \%$ in 2018 . However, only in the case of Hungary there was a decrease in the share of renewable energy in the final energy consumption from $12.74 \%$ in 2010 to $12.49 \%$ in 2018.

The next stage in creating a linear ordering of the EU countries with regard to the implementation of the SDG3 and SDG13 goals was to transform the characteristics considered as destimulants into stimulants and to perform the normalization, which leads to the deprivation of physical units of measurement results and the unification of orders of magnitude of features. The destimulants adopted in this study are presented in Table 4 . 
The increase in the value of these variables leads to the deterioration of the situation of countries in terms of achieving specific goals.

Table 4. Destimulants adopted in the study.

\begin{tabular}{cl}
\hline & \multicolumn{1}{c}{ SDG3 } \\
\hline$X_{3}$ & Smoking prevalence by sex (\% of population aged 15 or over) \\
\hline$X_{6}$ & $\begin{array}{l}\text { Self-reported unmet need for medical examination and care by sex (\% of population } \\
\text { aged 16 and over). }\end{array}$ \\
\hline$X_{8}$ & People killed in accidents at work, by sex (number per 100,000 employees). \\
\hline$X_{9}$ & $\begin{array}{l}\text { Population living in households considering that they suffer from noise, by poverty } \\
\text { status (\% of population). }\end{array}$ \\
\hline$X_{1}$ & Greenhouse gas emissions (tons per capita). \\
\hline$X_{2}$ & Greenhouse gas emissions intensity of energy consumption (index 2000 = 100). \\
\hline
\end{tabular}

The transformation of variables into stimulants was performed by means of a quotient transformation, determining the inverse value to the value of destimulant. Then the variables were normalized by means of zero unitarization. The normalized valuesof the variables made it possible to calculate the distance of each country in the European Union from the positive and negative ideal solutions. Then the TOPSIS method was used to calculate the values of a synthetic measure of the degree of achievement of the third and thirteenth goals for EU member states in the two years 2010 and 2018. The results of organizing the countries are shown in Table 5.

Using the Kendall rank correlation coefficient [119], the consistency of country orderings was determined. A statistically significant correlation was obtained only in the case of examining the relationships between the positions of countries due to the implementation of SDG13 in 2010 and 2018. The value of the Kendall rank correlation coefficient in this case was 0.635 . It is a positive correlation, so the countries that in 2010 had a better position in ordering due to the implementation of SDG13 also in 2018 had a better position. Twelve countries improved their place in order. The greatest positive change was noted in Greece-an improvement by 12 places and Bulgaria-by 7. Sixteen countries recorded a deterioration in the position in 2018 compared to the place in 2010. The biggest difference was in Germany-a decrease by 9 places and France-by 6 places. In the case of the remaining countries for which a decline in the ordering items in terms of SDG13 implementation was observed, the differences most often concern three or four items (e.g., Poland, Romania, Czech Republic and Estonia). The lowest (28) position in both analyzed years was occupied by Luxembourg, and the highest (from second to first) and slightly worse-in Latvia (drop from first to second). In the case of Luxembourg, in both analyzed years the values of the indicators in relation to SDG13 were very low. This country has the highest greenhouse gas emissions per capita. The per capita GHG emissions dropped from 25.5 tonnes to 20.3 tonnes over the period under review, but Luxembourg continues to emit the largest amount of GHG per capita among the countries surveyed. In addition, Luxembourg has the lowest percentage of the population covered by the Covenant of Mayors for Climate and Energy. Participation in the Agreement plays an important role in taking measures to increase energy efficiency and use renewable energy sources. The purpose of the Agreement is, inter alia, a reduction of at least $40 \%$ of $\mathrm{CO}_{2}$ emissions by 2030 . In addition, when analyzing the situation in Luxembourg, a very low share of renewable energy in gross final energy consumption by sector (\%) was recorded, compared to 2010, this percentage increased by slightly more than $6 \mathrm{pp}$. but it is one of the lowest. Sweden moved up from second to first place. This country has the lowest value of green house gas emissions (tonnes per capita). Compared to the amount of emissions in 2010 it decreased by $18 \%$. Since 2010, green house gas emissions intensity of energy consumption has decreased 
by an average of 3.35 percentage points each year. Of all the countries surveyed, Sweden also has the highest share of renewable energy in gross final energy consumption by sector, which is 2.5 times higher than the average for all countries.

Table 5. Ranking of EU countries according to the degree of implementation of SDG3 and SDG13 in 2010 and 2018.

\begin{tabular}{|c|c|c|c|c|c|c|}
\hline \multirow{3}{*}{ Countries } & \multicolumn{6}{|c|}{ Rank of Countries in Terms of Achieving } \\
\hline & \multicolumn{3}{|c|}{ SDG3 } & \multicolumn{3}{|c|}{ SDG13 } \\
\hline & 2010 & 2018 & Change & 2010 & 2018 & Change \\
\hline Austria & 24 & 5 & $\uparrow$ & 13 & 16 & $\downarrow$ \\
\hline Belgium & 10 & 17 & $\downarrow$ & 18 & 13 & $\uparrow$ \\
\hline Bulgaria & 18 & 14 & $\uparrow$ & 27 & 20 & $\uparrow$ \\
\hline Croatia & 23 & 8 & $\uparrow$ & 4 & 6 & $\downarrow$ \\
\hline Cyprus & 21 & 6 & $\uparrow$ & 25 & 21 & $\uparrow$ \\
\hline Czech Republic & 13 & 21 & $\downarrow$ & 20 & 24 & $\downarrow$ \\
\hline Denmark & 11 & 15 & $\downarrow$ & 8 & 3 & $\uparrow$ \\
\hline Estonia & 16 & 11 & $\uparrow$ & 15 & 19 & $\downarrow$ \\
\hline Finland & 5 & 12 & $\downarrow$ & 11 & 7 & $\uparrow$ \\
\hline France & 22 & 24 & $\downarrow$ & 9 & 15 & $\downarrow$ \\
\hline Germany & 9 & 16 & $\downarrow$ & 16 & 25 & $\downarrow$ \\
\hline Greece & 8 & 19 & $\downarrow$ & 23 & 11 & $\uparrow$ \\
\hline Hungary & 19 & 7 & $\uparrow$ & 7 & 12 & $\downarrow$ \\
\hline Ireland & 4 & 4 & - & 21 & 23 & $\downarrow$ \\
\hline Italy & 17 & 10 & $\uparrow$ & 12 & 8 & $\uparrow$ \\
\hline Latvia & 28 & 26 & $\uparrow$ & 1 & 2 & $\downarrow$ \\
\hline Lithuania & 25 & 27 & $\downarrow$ & 17 & 14 & $\uparrow$ \\
\hline Luxembourg & 7 & 20 & $\downarrow$ & 28 & 28 & - \\
\hline Malta & 15 & 2 & $\uparrow$ & 10 & 4 & $\uparrow$ \\
\hline Netherlands & 1 & 3 & $\downarrow$ & 22 & 26 & $\downarrow$ \\
\hline Poland & 27 & 25 & $\uparrow$ & 24 & 27 & $\downarrow$ \\
\hline Portugal & 20 & 28 & $\downarrow$ & 3 & 5 & $\downarrow$ \\
\hline Romania & 26 & 23 & $\uparrow$ & 6 & 9 & $\downarrow$ \\
\hline Slovakia & 14 & 18 & $\downarrow$ & 19 & 22 & $\downarrow$ \\
\hline Slovenia & 6 & 22 & $\downarrow$ & 14 & 17 & $\downarrow$ \\
\hline Spain & 12 & 9 & $\uparrow$ & 5 & 10 & $\downarrow$ \\
\hline Sweden & 3 & 1 & $\uparrow$ & 2 & 1 & $\uparrow$ \\
\hline United Kingdom & 2 & 13 & $\downarrow$ & 26 & 18 & $\uparrow$ \\
\hline
\end{tabular}

Certain regularities were noticed in the analysis of the implementation level of SDG3. For some countries (e.g., Austria, Croatia and Cyprus) a significantly better position was observed in 2018. On the other hand, for countries such as Slovenia, Luxembourg or Greece, a deterioration in the ordering position was noted. The best positions were recorded for two countries, i.e., Sweden and the Netherlands, and the worst—for Latvia, Poland and Portugal. The most favorable situation was in Sweden-a change from third to first place, and in the Netherlands-a drop by two places from first to third. Sweden owes its very good position in the linear ordering of countries in 2010 and 2018 to the values of all indicators related to SDG3. Attention should be paid to the low percentage of the population aged 15 and more reporting smoking, which has the lowest value in both analyzed years (a decrease by 9 percentage points from 16\% in 2010 to $7 \%$ in 2018). In addition, in the case of indicators such as: $X_{6}$-self-reported unmet need for medical examination and care by sex (\% of population aged 16 and over) or $X_{8}$-people killed in accidents at work, by sex (per 100,000 employees), a significant decrease was noted values (in the case of $X_{8}$ - the decrease was $0.33 \%$ from 1.23 to 0.9 per 100,000 employees). Portugal was last in the ranking in 2018. In eight years, her position has deteriorated by eight places. In both analyzed years, the value of the share of people with good or very good perceived health by sex ratio (\% of population aged 16 or over) remained at the same 
very low level-49.3\%. A high value was also noted for the share of people with good or very good perceived health by sex (\% of population aged 16 or over) indicator, amounting to almost 3\%, which is more than 1.6 times higher than the average value for all surveyed countries. In the analyzed period, the value of the percent age of population living in households considering that they suffer from noise, by poverty status did not improve. In both analyzed years, the value of this indicator was almost $23 \%$ and was on average 2.6 times higher than the lowest values (e.g., in 2018 compared to Croatia).

\section{Discussion}

In this study, we put tackling climate change and its impacts, and improving health and social well-being at the heart of the 17 SDGs. We argue that focusing more attention on the parallel and effective implementation of SDG3 and SDG13 goals will create better conditions for the transformational changes needed to achieve sustainable development faster. This is especially important today, when the whole world is facing both the climate crisis and the health crisis. The Covid-19 pandemic has shown that currently no country in the world meets the needs of its population in terms of health and social well-being. In addition, a lack of effective climate action can exacerbate the emergence of more frequent infectious disease outbreaks and enhance other health impacts related to environmental threats, thereby reducing the vulnerability of entire societies to various pathogens.

Looking to the future, the SDGs aim to address the complex and multidimensional challenges of social, economic and environmental sustainability [120]. According to the current development paradigm, SDG goals are characterized by both positive and negative interactions [121]. In this study, we show how the degree of achievement of the SDG3 and SDG13 goals differs and what the interactions between them are in the EU countries. The results show that in the implementation of the SDG3 and SDG13 objectives in the EU countries, three phenomena are noticeable-synergy, compromise and concurrency. Synergy means that improving the degree of achievement for one goal fosters progress in another. Compromise means that progress towards one goal hampers progress on another. In turn, concurrency is manifested by a simultaneous decrease in the progress in the implementation of both SDGs. Synergies between the SDG3 and SGD13 objectives were recorded in only five countries, i.e., Bulgaria, Cyprus, Italy, Malta and Sweden. In these countries, in 2018, compared to 2010, there was an improvement in the effectiveness of the implementation of actions taken to counteract climate change and its effects, with a simultaneous improvement in health and social well-being. A group of these countries significantly improved indicators relating to health and public access to healthcare. At the same time, greenhouse gas emissions and their intensity decreased in these countries, and the share of renewable energy use increased. The effectiveness of the implementation of these activities in this group of countries varied. Bulgaria, despite the improvement in the effectiveness of achieving the SDG3 and SDG13 goals, still ranks low in the ranking of EU countries, in particular in the case of SDG13. Cyprus made significant changes in its efforts to improve health and social well-being, occupying the 6th position among the EU countries, while slightly improving the effectiveness of achieving the SDG13 objectives (from 25th to 21st position). Italy was in the top ten in the ranking of EU countries and the effectiveness of achieving the SDG3 and SDG13 goals improved significantly in this country. The greatest improvement in the effectiveness of achieving the SDG3 and SDG13 targets was recorded in Malta. In turn, Sweden ranks first in the ranking of EU Member States in terms of the effectiveness of achieving goals related to both climate change and health and social well-being. This is due to the fact that this country has adopted ambitious and stable environmental policies that are characterized by broad social and political acceptance, long-term horizons and a fairly high degree of environmental integration or environmental policy in other policy areas [91]. Sweden has also adopted a number of decisions, strategies and action plans which have priority for human health. These activities focus, inter alia, on: (a) Social sustainability and reduced health inequalities throughout the life cycle, from early life to old age. Gender equality and nondiscrimination are of central importance; (b) 
preventing ill health by reducing the prevalence of risk factors for ill health; (c) promoting health by working for more healthy societies in order to strengthen people's physical, mental and social well-being and facilitating good lifestyles; (d) improving access to basic health services for good health and health equity for all; and (e) the development and reinforcement of health systems that are effective, sustainable and resilient in economic, environmental and social terms and have effective and fair financing [122].These activities undoubtedly contribute to the great success of this country in achieving the sustainable development goals related to climate and health.

In other EU countries, there was a compromise or concurrency, manifested by a simultaneous decline in the effectiveness of achieving the SDG3 and SDG13 goals. Kroll et al. [3] prove that when the SDG13 is linked to other SDG objectives, compromises are a common precedent. In turn, Kettner et al. [84] suggest that especially the achievement of goals in the social and environmental dimensions is often regarded as contradictory or even mutually exclusive.

Our analysis reveals that the implementation of the SDG3 and SDG13 goals in most EU countries (15) was manifested by a compromise between them (Figure 2). In 9 countries, this compromise focused on improving efficiency in meeting the health goal and generating wealth at the expense of environmental sustainability. Countries such as Austria, Croatia, Estonia, Hungary, Ireland, Latvia, Poland, Romania and Spain provided varying degrees of better social welfare, but reduced significantly the effectiveness of climate change measures. Among these countries, Austria, Croatia and Hungary rank high in the ranking of EU countries in terms of improving the effectiveness of SDG3 implementation, which means that they are much closer to achieving them than the other countries. In the remaining EU countries (6) where there was a trade-off between the achievement of the SDG3 and SDG13 goals, as they managed to improve the achievement of climate change goals, the implementation of actions related to the improvement of health and social welfare deteriorated. The greatest improvement in the effectiveness of SDG13 in these countries was recorded in Denmark and Greece.

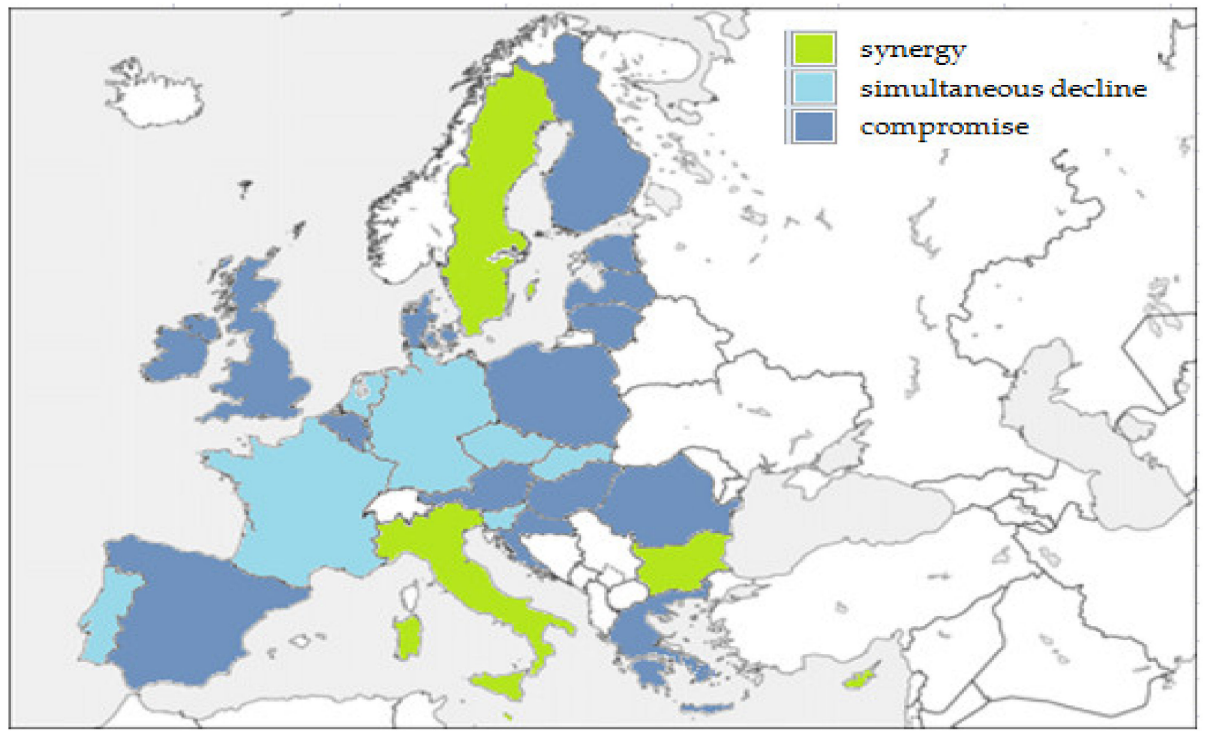

Figure 2. Map of synergies and compromises in the implementation of the SDG13 and SDG3 sustainable development goals in EU countries.

In $8 \mathrm{EU}$ countries, a simultaneous decline in the effectiveness of the implementation of the SDG3 and SDG13 goals was recorded. The ranking of EU countries in terms of improving the effectiveness of the implementation of the sustainable development goals in the area of health and well-being and counteracting climate change and its effects shows that Poland, as one of the few EU countries, next to the Czech Republic and Luxembourg, lags far behind the effective implementation of these goals. Despite the fact that in Poland there 
has been a slight improvement in the implementation of SDG3, the country still ranks very low in the ranking of EU countries in terms of the effectiveness of achieving goals related to climate change and health and social well-being. The low degree of implementation of individual activities under the SDG3 and SDG13 objectives may seriously jeopardize the implementation of the 2030 Agenda, which emphasizes the need to support innovation and policies that can make our cities and communities more sustainable, as well as strengthen social transformation and stimulate a number of institutions to act in the field of climate, health and social well-being $[3,81]$.

\section{Conclusions}

For the research presented in this article, we compiled a comprehensive set of indicators for two of the 17 SDGs_-SDG3 "Good health and well-being" and SDG13 "Climate action", and ranked the 28 EU Member States to illustrate their progress towards effectiveness the achievement of these goals and the interaction between them.

The presented study showed the diversity in the implementation of the sustainable development goals relating to the improvement of health and social well-being as well as the fight against climate change and its effects in the EU countries.

First, the study provides evidence that only a few EU countries have seen significant improvements in the implementation of measures to improve health and social well-being and to combat climate change and its impacts. It has been shown that in 2018, compared to 2010, the degree of SDG3 implementation in thirteen EU countries improved. The countries such as Austria, Croatia, Cyprus, Hungary, Malta and Sweden improved their position in the implementation of SDG3 to the greatest extent. In these countries, indicators describing access to healthcare and good health of the population improved significantly. Among the 28 EU countries, eleven of them improved the degree of SDG13 implementation, of which the largest changes were recorded only in four countries, i.e., Denmark, Greece, Malta and Sweden. The study shows that energy policy plays a huge role in improving the effectiveness of SDG13 implementation.

Secondly, the study showed that, in practice, synergy in achieving SDG3 and SDG13 objectives in EU countries is of low priority. Policymakers in many countries have limited ambition to fruitfully combine these specific social goals (SDG3) with environmental goals (SDG13). The implementation of these goals in most EU countries is based on a compromise rather than a synergy. Specifically, the analysis found that in fifteen EU countries, improvement in one target came at the expense of another. EU countries that showed synergy between the implementation of the SDG3 and SDG13 objectives can be an example for others. These countries show that the effective implementation of actions to improve health and social welfare went hand in hand with actions taken to counteract climate change and its consequences. This is particularly important for those countries where climate change and the improvement of health have not yet been identified as priorities in achieving the SDGs.

Finally, our study provides evidence that apart from the phenomenon of synergy and compromise, there may be a phenomenon characterized by a simultaneous decrease in the effectiveness of achieving both objectives. This is quite a worrying phenomenon considering that both climate change and health and social well-being should be among the top priorities in all Member States in order to boost the process of social, economic and environmental sustainability.

Our findings contribute to contemporary debates on the effectiveness of the implementation of individual SDGs and the growing importance of interactions between environmental and social SDGs, including SDG3 and SDG13. This study proves that decision-makers from many EU countries will have to deal with the dilemma of the urgency of achieving individual SDGs without jeopardizing the achievement of other goals. Urgent coordination of actions aimed at improving health and social well-being as well as counteracting climate change and its effects may have a positive impact on the success of the implementation of other sustainable development goals. 
The conducted research does not fully solve the problem of the interaction between the SDG3 and SDG13 goals. Future research in this area should repeat the existing ones in order to identify further actions in individual EU countries in achieving the SDG3 and SDG13 objectives and interactions between them. This is important because of the high volatility of social, economic and environmental conditions currently facing all countries in the world. In particular, it is worth analyzing how the COVID-19 pandemic influenced the achievement of these goals and their interaction. In particular, whether it was an impulse to intensify actions in the field of health and climate or, on the contrary, it inhibited their implementation. It is also important to pay attention to the potential impact of the energy transition processes from the perspective of the impact on climate, health and social well-being. There is also a need for more in-depth research to establish the mechanisms, direction and causality underlying the achievement of SDG3 and SDG13 objectives and their interactions. Filling the gap in this area will additionally provide the basis for creating an evidence-based sustainable development policy.

Author Contributions: Conceptualization, A.K.-K. and A.S.-R.; methodology, A.S.-R.; software, A.S.-R.; validation, A.S.-R.; formal analysis, A.K.-K. and A.S.-R.; investigation, A.K.-K. and A.S.-R.; resources, A.K.-K. and A.S.-R.; data curation, A.K.-K. and A.S.-R.; writing-original draft preparation, A.K.-K. and A.S.-R.; writing-review and editing, A.K.-K. and A.S.-R.; visualization, A.K.-K. and A.S.R.; supervision, A.K.-K. and A.S.-R.; project administration, A.K.-K. and A.S.-R.; funding acquisition, A.K.-K. and A.S.-R. All authors have read and agreed to the published version of the manuscript.

Funding: This research received no external funding.

Conflicts of Interest: The authors declare no conflict of interest.

\section{References}

1. United Nations Sustainable Development Goals. 2016. Available online: https://sustainabledevelopment.un.org/ (accessed on 26 January 2020).

2. Nerini, F.F.; Tomei, J.; To, L.S.; Bisaga, I.; Parikh, P.; Black, M.; Borrion, A.; Spataru, C.; Broto, V.C.; Anandarajah, G.; et al. Mapping synergies and trade-offs between energy and the Sustainable Development Goals. Nat. Energy 2018, 3, 10-15. [CrossRef]

3. Kroll, C.; Warchold, A.; Pradhan, P. Sustainable Development Goals (SDGs): Are we successful in turning trade-offs into synergies? Palgrave Commun. 2019, 5, 1-11. [CrossRef]

4. Alcamo, J.; Grundy, C.; Scharlemann, J. Interactions among the Sustainable Development Goals, and Why They Are Important. SSRP (Sussex Sustainability Research Programme); University of Sussex and Institute of Development Studies: Brighton, UK, 2020.

5. Gong, X.; Liu, Y.; Sun, T. Evaluating Climate Change Governance Using the Polity-Policy-Politics, Framework: A Comparative Study of China and the United States. Sustainability 2020, 12, 6403. [CrossRef]

6. Albright, K.; Shah, P.; Santodomingo, M.; Scandlyn, J. Dissemination of Information About Climate Change by State and Local Public Health Departments: United States, 2019-2020. Am. J. Public Health 2020, 110, 1184-1190. [CrossRef]

7. World Health Organization. Climate Change and Human Health-Risks and Responses. Available online: https://www.who.int/ globalchange/summary/en/index2.html (accessed on 26 January 2020).

8. European Commission. The Macroeconomic and Other Benefits of Energy Efficiency; European Union: Brussels, Belgium, 2016; Available online: https:/ / ec.europa.eu/energy/sites/ener/files/documents / final_report_v4_final.pdf (accessed on 26 January 2020).

9. Dawes, J.H. Are the Sustainable Development Goals self-consistent and mutually achievable? Sustain. Dev. 2020, 28, 101-117. [CrossRef]

10. Campbell, B.M.; Hansen, J.; Rioux, J.; Stirling, C.M.; Twomlow, S.; Wollenberg, E. (Lini) Urgent action to combat climate change and its impacts (SDG 13): Transforming agriculture and food systems. Curr. Opin. Environ. Sustain. 2018, 34, 13-20. [CrossRef]

11. Markkanen, S.; Anger-Kraavi, A. Social impacts of climate change mitigation policies and their implications for inequality. Clim. Policy 2019, 19, 827-844. [CrossRef]

12. Boyer, C.J.; Bowen, K.; Murray, V.; Hadley, J.; Hilly, J.J.; Hess, J.J.; Ebi, K.L. Using Implementation Science For Health Adaptation: Opportunities For Pacific Island Countries. Health Aff. 2020, 39, 2160-2167. [CrossRef]

13. Salas, R.N. Climate action: The best gift for global health. BMJ 2020, 371, m4723. [CrossRef] [PubMed]

14. Arroyo, F.R.; Miguel, L.J. The Role of Renewable Energies for the Sustainable Energy Governance and Environmental Policies for the Mitigation of Climate Change in Ecuador. Energies 2020, 13, 3883. [CrossRef]

15. Vermeulen, S.J.; Campbell, B.M.; Ingram, J.S. Climate Change and Food Systems. Annu. Rev. Environ. Resour. 2012, 37, 195-222. [CrossRef]

16. Galway, L.P.; Beery, T.; Jones-Casey, K.; Tasala, K. Mapping the Solastalgia Literature: A Scoping Review Study. Int. J. Environ. Res. Public Health 2019, 16, 2662. [CrossRef] 
17. Patz, J.A.; Campbell-Lendrum, D.; Holloway, T.; Foley, J.A. Impact of Regional Climate Change on Human Health. Nature 2005, 438, 310-317. [CrossRef]

18. Hrabok, M.; Delorme, A.; Agyapong, V.I. Threats to Mental Health and Well-Being Associated with Climate Change. J. Anxiety Disord. 2020, 76, 102295. [CrossRef] [PubMed]

19. Linares, C.; Díaz, J.; Negev, M.; Martínez, G.S.; Debono, R.; Paz, S. Impacts of climate change on the public health of the Mediterranean Basin population-Current situation, projections, preparedness and adaptation. Environ. Res. 2020, $182,109107$. [CrossRef] [PubMed]

20. Krasna, H.; Czabanowska, K.; Jiang, S.; Khadka, S.; Morita, H.; Kornfeld, J.; Shaman, J. The Future of Careers at the Intersection of Climate Change and Public Health: What Can Job Postings and an Employer Survey Tell Us? Int. J. Environ. Res. Public Health 2020, 17, 1310. [CrossRef] [PubMed]

21. Fox, M.; Zuidema, C.; Bauman, B.; Burke, T.; Sheehan, M. Integrating Public Health into Climate Change Policy and Planning: State of Practice Update. Int. J. Environ. Res. Public Health 2019, 16, 3232. [CrossRef] [PubMed]

22. Bai, L.; Yang, J.; Zhang, Y.; Zhao, D.; Su, H. Durational effect of particulate matter air pollution wave on hospital admissions for schizophrenia. Environ. Res. 2020, 187, 109571. [CrossRef] [PubMed]

23. Onozuka, D.; Gasparrini, A.; Sera, F.; Hashizume, M.; Honda, Y. Future projections of temperature-related excess out-of-hospital cardiac arrest under climate change scenarios in Japan. Sci. Total. Environ. 2019, 682, 333-339. [CrossRef]

24. Alahmad, B.; Ahmed, F.; Haitham Khraishah, S.; Alseaidan, M.; Gasana, J.; Al-Hemoud, A.; Koutrakis, P.; Fox, M.A. Ex-treme temperatures and mortality in Kuwait: Who is vulnerable? Sci. Total Environ. 2020, 732, e139289. [CrossRef] [PubMed]

25. Tang, C.; Liu, X.; He, Y.; Gao, J.; Xu, Z.; Duan, J.; Yi, W.; Wei, Q.; Pan, R.; Song, S.; et al. Association between extreme precipitation and ischemic stroke in Hefei, China: Hospitalization risk and disease burden. Sci. Total. Environ. 2020, 732, 139272. [CrossRef] [PubMed]

26. Yang, L.; Liu, C.; Bi, P.; Vardoulakis, S.; Huang, C. Local actions to health risks of heatwaves and dengue fever under climate change: Strategies and barriers among primary healthcare professionals in southern China. Environ. Res. 2020, 187, 109688. [CrossRef] [PubMed]

27. World Health Organization. WHO Calls for Urgent Action to Protect Health from Climate Change-Sign the Call. 2015. Available online: http:/ / www.who.int/globalchange/global-campaign/cop21/en/ (accessed on 27 November 2020).

28. Garcia, D.M.; Sheehan, M.C. Extreme Weather-driven Disasters and Children's Health. Int. J. Health Serv. 2015, 46, 79-105. [CrossRef] [PubMed]

29. Araos, M.; Austin, S.E.; Berrang-Ford, L.; Ford, J.D. Public Health Adaptation to Climate Change in Large Cities. Int. J. Health Serv. 2015, 46, 53-78. [CrossRef]

30. Watts, N.; Amann, M.; Ayeb-Karlsson, S.; Belesova, K.; Bouley, T.; Boykoff, M.; Byass, P.; Cai, W.; Campbell-Lendrum, D.; Chambers, J.; et al. The Lancet Countdown on Health and Climate Change: From 25 Years of Inaction to a Global Trans-formation for Public Health. Lancet 2018, 391, 581-630. [CrossRef]

31. Costello, A.; Abbas, M.; Allen, A.; Ball, S.; Bell, S.; Bellamy, R.; Friel, S.; Groce, N.; Johnson, A.; Kett, M.; et al. Managing the health effects of climate change: Lancet and University College London Institute for Global Health Commission. Lancet 2009, 373, 1693-1733. [CrossRef]

32. McMichael, A.J.; Woodruff, E.R.; Hales, S. Climate change and human health: Present and future risks. Lancet 2006, 367, 859-869. [CrossRef]

33. McMichael, A. Climate Change and the Health of Nations: Famines, Fevers, and the Fate of Populations; Oxford University Press: Oxford, UK, 2017.

34. Hayes, K.; Blashki, G.; Wiseman, J.; Burke, S.; Reifels, L. Climate change and mental health: Risks, impacts and priority actions. Int. J. Ment. Health Syst. 2018, 12, 1-12. [CrossRef]

35. Hayes, K.; Berry, P.; Ebi, K.L. Factors Influencing the Mental Health Consequences of Climate Change in Canada. Int. J. Environ. Res. Public Health 2019, 16, 1583. [CrossRef]

36. Sheehan, M.C.; Fox, M.A. Early Warnings: The Lessons of COVID-19 for Public Health Climate Preparedness. Int. J. Health Serv. 2020, 50, 264-270. [CrossRef]

37. Renda, A.; Castro, R.J. Towards Stronger EU Governance of Health Threats after the COVID-19 Pandemic. Eur. J. Risk Regul. 2020, 11, 273-282. [CrossRef]

38. Climat Risk Disclosure Barometer. 2020. Study Belgium, How are Your Climate Change Disclosures Revealing the True Risks and Opportunities of Your Business? Available online: https:/ /www.ey.com/en_be/climate-related-reporting (accessed on 7 November 2020).

39. Ebi, K.L.; Berry, P.; Campbell-Lendrum, D.; Cissé, G.; Hess, J.; Ogden, N.; Schnitter, R. Health System Adaptation to Climate Variability and Change; Global Commission on Adaptation: Rotterdam, The Netherlands, 2019.

40. Beccari, B. A Comparative Analysis of Disaster Risk, Vulnerability and Resilience Composite Indicators. PLoS Curr. 2016, 8. [CrossRef] [PubMed]

41. Davis, E.C.; Rossati, A.; Bargiacchi, O.; Garavelli, P.L.; McMichael, A.J.; Juliusson, G. Globalization, Climate Change, and Human Health. N. Engl. J. Med. 2013, 369, 94-96. [CrossRef] [PubMed]

42. Coccia, M. Factors determining the diffusion of COVID-19 and suggested strategy to prevent future accelerated viral infectivity similar to COVID. Sci. Total. Environ. 2020, 729, 138474. [CrossRef] [PubMed] 
43. Méndez-Arriaga, F. The temperature and regional climate effects on communitarian COVID-19 contagion in Mexico throughout phase 1. Sci. Total. Environ. 2020, 735, 139560. [CrossRef] [PubMed]

44. Yao, Y.; Pan, J.; Wang, W.; Liu, Z.; Kan, H.; Qiu, Y.; Meng, X.; Wang, W. Association of particulate matter pollution and case fatality rate of COVID-19 in 49 Chinese cities. Sci. Total. Environ. 2020, 741, 140396. [CrossRef]

45. Zhu, Y.; Xie, J.; Huang, F.; Cao, L. Association between short-term exposure to air pollution and COVID-19 infection: Evidence from China. Sci. Total Environ. 2020, 727, 138704. [CrossRef]

46. Zoran, M.A.; Savastru, R.S.; Savastru, D.M.; Tautan, M.N. Assessing the relationship between surface levels of PM2.5 and PM10 particulate matter impact on COVID-19 in Milan, Italy. Sci. Total. Environ. 2020, 738, 139825. [CrossRef]

47. Pramanik, M.; Udmale, P.; Bisht, P.; Chowdhury, K.; Szabo, S.; Pal, I. Climatic factors influence the spread of COVID-19 in Russia. Int. J. Environ. Health Res. 2020, 16, 1-15. [CrossRef]

48. Coro, G. A global-scale ecological niche model to predict SARS-CoV-2 coronavirus infection rate. Ecol. Model. 2020, 431 , e109187. [CrossRef]

49. Rosario, D.K.A.; Mutz, Y.S.; Bernardes, P.C.; Conte-Junior, C.A. Relationship between COVID-19 and weather: Case study in a tropical country. Int. J. Hyg. Environ. Health 2020, 229, 113587. [CrossRef]

50. Sobral, M.F.F.; Duarte, G.B.; da Penha Sobral, A.I.G.; Marinho, M.L.M.; de Souza Melo, A. Association between climate variables and global transmission of SARS-CoV-2. Sci. Total Environ. 2020, 729, e138997. [CrossRef]

51. Ahmadi, M.; Sharifi, A.; Dorosti, S.; Ghoushchi, S.J.; Ghanbari, N. Investigation of effective climatology parameters on COVID-19 outbreak in Iran. Sci. Total. Environ. 2020, 729, 138705. [CrossRef]

52. Watts, N.; Adger, W.N.; Agnolucci, P.; Blackstock, J.; Byass, P.; Cai, W.; Chaytor, S.; Colbourn, T.; Collins, M.; Cooper, A.; et al. Health and climate change: Policy responses to protect public health. Lancet 2015, 386, 1861-1914. [CrossRef]

53. Mccollum, D.L.; Krey, V.; Riahi, K. An integrated approach to energy sustainability. Nat. Clim. Chang. 2011, 1, 428-429. [CrossRef]

54. Knodt, M.; Piefer, N. Conceptualizing Emerging Powers and EU Energy Governance: Towards a Research Agenda. Chall. Eur. Extern. Energy Gov. Emerg. Powers 2016, 49-64. [CrossRef]

55. Szlávik, J.; Csete, M. Climate and Energy Policy in Hungary. Energies 2012, 5, 494-517. [CrossRef]

56. Sano, F.; Akimoto, K.; Wada, K. Impacts of different diffusion scenarios for mitigation technology options and of model representations regarding renewables intermittency on evaluations of CO2 emissions reductions. Clim. Chang. 2014, 123, 665-676. [CrossRef]

57. Bhardwaj, A.; Joshi, M.; Khosla, R.; Dubash, N.K. More priorities, more problems? Decision-making with multiple energy, development and climate objectives. Energy Res. Soc. Sci. 2019, 49, 143-157. [CrossRef]

58. Kettner, C.; Kletzan-Slamanig, D.; Köppl, A.; Littig, B.; Zielinska, I. A Cross-Country Comparison of Sustainable Energy Development in Selected EU Members. J. Sustain. Res. 2019, 1. [CrossRef]

59. Santika, W.G.; Anisuzzaman, M.; Bahri, P.A.; Shafiullah, G.; Rupf, G.V.; Urmee, T. From goals to joules: A quantitative approach of interlinkages between energy and the Sustainable Development Goals. Energy Res. Soc. Sci. 2019, 50, 201-214. [CrossRef]

60. Bertheau, P. Assessing the impact of renewable energy on local development and the Sustainable Development Goals: Insights from a small Philippine island. Technol. Forecast. Soc. Chang. 2020, 153, 119919. [CrossRef]

61. Wang, C.-N.; Ho, H.-X.T.; Hsueh, M.-H. An Integrated Approach for Estimating the Energy Efficiency of Seventeen Countries. Energies 2017, 10, 1597. [CrossRef]

62. Urban, F.; Nordensvärd, J. Low Carbon Energy Transitions in the Nordic Countries: Evidence from the Environmental Kuznets Curve. Energies 2018, 11, 2209. [CrossRef]

63. Hajdukiewicz, A.; Pera, B. International Trade Disputes over Renewable Energy-the Case of the Solar Photovoltaic Sector. Energies 2020, 13, 500. [CrossRef]

64. Zamasz, K.; Kapłan, R.; Kaszyński, P.; Saługa, P.W. An Analysis of Support Mechanisms for New CHPs: The Case of Poland. Energies 2020, 13, 5635. [CrossRef]

65. Moriarty, P.; Honnery, D. Feasibility of a 100\% Global Renewable Energy System. Energies 2020, 13, 5543. [CrossRef]

66. Watts, N.; Amann, M.; Ayeb-Karlsson, S.; Belesova, K.; Bouley, T.; Boykoff, M.; Byass, P.; Cai, W. The 2017 Report of the Lancet Countdown: From 25 Years of Inaction to a Global Transformation for Public Health. 2017. Available online: https:/ /www.researchgate.net/publication/320727776_The_2017_report_of_the_Lancet_Countdown_from_25_years_of_ inaction_to_a_global_transformation_for_public_health_A_Review_by_The_Lancet (accessed on 4 April 2021).

67. Tcvetkov, P. Climate Policy Imbalance in the Energy Sector: Time to Focus on the Value of $\mathrm{CO}_{2}$ Utilization. Energies 2021, 14, 411. [CrossRef]

68. Gao, M.Z.A.; Fan, C.-T.; Liao, C.-N. Application of German energy transition in Taiwan: A critical review of unique elec-tricity liberalisation as a core strategy to achieve renewable energy growth. Energy Policy 2018, 120, 644-654. [CrossRef]

69. Wang, C.-N.; Tibo, H.; Duong, D.H. Renewable Energy Utilization Analysis of Highly and Newly Industrialized Countries Using an Undesirable Output Model. Energies 2020, 13, 2629. [CrossRef]

70. Manowska, A.; Nowrot, A. The Importance of Heat Emission Caused by Global Energy Production in Terms of Climate Impact. Energies 2019, 12, 3069. [CrossRef]

71. Ziolo, M.; Jednak, S.; Savić, G.; Kragulj, D. Link between Energy Efficiency and Sustainable Economic and Financial Development in OECD Countries. Energies 2020, 13, 5898. [CrossRef]

72. Kaur, A. Impact of climate change on human health. Int. J. Yogic Hum. Mov. Sports Sci. 2018, 3, 81-83. 
73. Pascaris, A.S.; Pearce, J.M. U.S. Greenhouse Gas Emission Bottlenecks: Prioritization of Targets for Climate Liability. Energies 2020, 13, 3932. [CrossRef]

74. Intergovernmental Panel on Climate Change. Climate Change 2014: Mitigation of Climate Change. Contribution of Working Group III to the Fifth Assessment Report of the Intergovernmental Panel on Climate Change; Cambridge University Press: Cambridge, UK, 2014.

75. Hanlon, P.; Carlisle, S. Do we face a third revolution in human history? If so, how will public health respond? J. Public Health 2008, 30, 355-361. [CrossRef]

76. Keles, R. The Quality of Life and the Environment. Procedia Soc. Behav. Sci. 2012, 35, 23-32. [CrossRef]

77. Salas, R.N.; Jha, A.K. Climate change threatens the achievement of effective universal healthcare. BMJ 2019, 366, 5302. [CrossRef] [PubMed]

78. Moriarty, P.; Honnery, D. Energy Efficiency or Conservation for Mitigating Climate Change? Energies 2019, 12, 3543. [CrossRef]

79. Lelieveld, J.; Evans, J.S.; Fnais, M.; Giannadaki, D.; Pozzer, A. The contribution of outdoor air pollution sources to prem-ature mortality on a global scale. Nature 2015, 525, 367-371. [CrossRef] [PubMed]

80. Scharlemann, J.P.W.; Brock, R.C.; Balfour, N.; Brown, C.; Burgess, N.D.; Guth, M.K.; Ingram, D.J.; Lane, R.; Martin, J.G.C.; Wicander, S.; et al. Towards understanding interactions between Sustainable Development Goals: The role of environment-human linkages. Sustain. Sci. 2020, 15, 1573-1584. [CrossRef]

81. Pradhan, P.; Costa, L.; Rybski, D.; Lucht, W.; Kropp, J.P. A Systematic Study of Sustainable Development Goal (SDG) Interactions. Earth's Future 2017, 5, 1169-1179. [CrossRef]

82. Orchard, S.; Glover, D.; Karki, S.T.; Ayele, S.; Sen, D.; Rathod, R.; Rowhani, P. Exploring synergies and trade-offs among the sustainable development goals: Collective action and adaptive capacity in marginal mountainous areas of India. Sustain. Sci. 2019, 15, 1-17. [CrossRef]

83. Nilsson, M.; Chisholm, E.; Griggs, D.; Howden-Chapman, P.; Mccollum, D.; Messerli, P.; Neumann, B.; Stevance, A.-S.; Visbeck, M.; Stafford-Smith, M. Mapping interactions between the sustainable development goals: Lessons learned and ways forward. Sustain. Sci. 2018, 13, 1489-1503. [CrossRef]

84. Kettner, C.; Kletzan-Slamanig, D.; Köppl, A.; Littig, B.; Zielinska, I. Monitoring Sustainable Development: Climate and Energy Policy Indicators. J. Sustain. Res. 2020, 2, e200027. [CrossRef]

85. Forestier, O.; Kim, R.E. Cherry-picking the Sustainable Development Goals: Goal prioritization by national governments and implications for global governance. Sustain. Dev. 2020, 28, 1269-1278. [CrossRef]

86. Cernev, T.; Fenner, R. The importance of achieving foundational Sustainable Development Goals in reducing global risk. Futures 2020, 115, 102492. [CrossRef]

87. Körfgen, A.; Förster, K.; Glatz, I.; Maier, S.; Becsi, B.; Meyer, A.; Kromp-Kolb, H.; Stötter, J. It's a Hit! Mapping Austrian Research Contributions to the Sustainable Development Goals. Sustainability 2018, 10, 3295. [CrossRef]

88. Van Soest, H.L.; van Vuuren, D.P.; Hilaire, J.; Minx, J.C.; Harmsen, M.J.; Krey, V.; Popp, A.; Riahi, K.; Luderer, G. Analysing interactions among Sustainable Development Goals with Integrated Assessment Models. Glob. Transit. 2019, 1, 210-225. [CrossRef]

89. Ramos, C.D.M.; Laurenti, R. Towards the Agenda 2030: A Quantitative Analysis of Synergies and Trade-Offs between the SDGs of Spain during 2000-2019. Sustainability 2020, 12, 506. [CrossRef]

90. Collste, D.; Pedercini, M.; Cornell, S.E. Policy coherence to achieve the SDGs: Using integrated simulation models to assess effective policies. Sustain. Sci. 2017, 12, 921-931. [CrossRef]

91. Weitz, N.; Nilsson, M.; Davis, M. A Nexus Approach to the Post-2015 Agenda: Formulating Integrated Water, Energy, and Food SDGs. SAIS Rev. Int. Aff. 2014, 34, 37-50. [CrossRef]

92. Fu, B.; Wang, S.; Zhang, J.; Hou, Z.; Li, J. Unravelling the complexity in achieving the 17 sustainable-development goals. Natl. Sci. Rev. 2019, 6, 386-388. [CrossRef]

93. Lacey, F.G.; Henze, D.K.; Lee, C.J.; van Donkelaar, A.; Martin, R.V. Transient climate and ambient health impacts due to national solidfuel cookstove emissions. Proc. Natl. Acad. Sci. USA 2017, 114, 1269-1274. [CrossRef]

94. Zhao, Z.; Cai, M.; Wang, F.; Winkler, J.A.; Connor, T.; Chung, M.G.; Zhang, J.; Yang, H.; Xu, Z.; Tang, Y.; et al. Synergies and tradeoffs among Sustainable Development Goals across boundaries in a metacoupled world. Sci. Total. Environ. 2021, 751, 141749. [CrossRef]

95. Hutton, C.W.; Nicholls, R.J.; Lázár, A.N.; Chapman, A.; Schaafsma, M.; Salehin, M. Potential Trade-Offs between the Sustainable Development Goals in Coastal Bangladesh. Sustainability 2018, 10, 1108. [CrossRef]

96. Bennich, T.; Weitz, N.; Carlsen, H. Deciphering the scientific literature on SDG interactions: A review and reading guide. Sci. Total. Environ. 2020, 728, 138405. [CrossRef] [PubMed]

97. Weitz, N.; Carlsen, H.; Nilsson, M.; Skånberg, K. Towards systemic and contextual priority setting for implementing the 2030 Agenda. Sustain. Sci. 2018, 13, 531-548. [CrossRef] [PubMed]

98. Scherer, L.; Behrens, P.; de Koning, A.; Heijungs, R.; Sprecher, B.; Tukker, A. Trade-offs between social and environmental Sustainable Development Goals. Environ. Sci. Policy 2018, 90, 65-72. [CrossRef]

99. Le Blanc, D. Towards Integration at Last? The Sustainable Development Goals as a Network of Targets; DESA Working Paper No 141. ST/ESA/2015/DWP/141; UN Department of Economic and Social Affairs: New York, NY, USA, 2015; Available online: http://www.un.org/esa/desa/papers/2015/wp141_2015.pdf (accessed on 19 February 2021). 
100. Huan, Y.; Liang, T.; Li, H.; Zhang, C. A systematic method for assessing progress of achieving sustainable development goals: A case study of 15 countries. Sci. Total. Environ. 2021, 752, 141875. [CrossRef]

101. Liu, J.; Hull, V.; Godfray, H.C.J.; Tilman, D.; Gleick, P.; Hoff, H.; Pahl-Wostl, C.; Xu, Z.; Chung, M.G.; Sun, J.; et al. Nexus approaches to global sustainable development. Nat. Sustain. 2018, 1, 466-476. [CrossRef]

102. Breuer, A.; Janetschek, H.; Malerba, D. Translating Sustainable Development Goal (SDG) Interdependencies into Policy Advice. Sustainability 2019, 11, 2092. [CrossRef]

103. Allen, C.; Metternicht, G.; Wiedmann, T. Prioritising SDG targets: Assessing baselines, gaps and interlinkages. Sustain. Sci. 2019, 14, 421-438. [CrossRef]

104. Alcamo, J.; Thompson, J.; Alexander, A.; Antoniades, A.; Delabre, I.; Dolley, J.; Marshall, F.; Menton, M.; Middleton, J.; Scharlemann, J.P.W. Analysing interactions among the sustainable development goals: Findings and emerging issues from local and global studies. Sustain. Sci. 2020, 15, 1561-1572. [CrossRef] [PubMed]

105. Gomez-Echeverri, L. Climate and development: Enhancing impact through stronger linkages in the implementation of the Paris Agreement and the Sustainable Development Goals (SDGs). Philos. Trans. R. Soc. A. 2018, 376, 2119. [CrossRef] [PubMed]

106. Berger-Schmitt, R.; Noll, H.-H. Conceptual Framework and Structure of a European System of Social Indicators; Working Paper 9; EuReporting: Mannheim, Germany, 2000.

107. Eurostat-Database. Available online: https:/ / ec.europa.eu/eurostat/data/database (accessed on 26 January 2020).

108. Wysocki, F. The Methods of Taxonomy for Recognition of Economic Types in Agriculture and Rural Areas; University Publisher Poznan University of Life Sciences: Poznań, Poland, 2010.

109. Sompolska-Rzechuła, A. Selection of the Optimal Way of Linear Ordering of Objects: Case of Sustainable Development in EU Countries. Stat. Stat.Econ. J. 2021, 101, 365-377.

110. Kukuła, K. Zero Unitarization Method; Scientific Publisher PWN: Warsaw, Poland, 2000.

111. Hwamg, C.L.; Yoon, K. Multiple Attribute Decision Making. Methods and Applications; Springer: Berlin, Germany, 1981.

112. Łuczak, A.; Kalinowski, S. Assessing the level of the material deprivation of European Union countries. PLoS ONE 2020, 15, e0238376. [CrossRef] [PubMed]

113. Yılmaz, G.; İnel, N.M. Assessment of Sustainability Performances of Banks by TOPSIS method and Balanced Scorecard Approach. Int. J. Bus. Appl. Soc. Sci. 2018, 4, 62-75. Available online: https://nbnresolving.org/urn:nbn:de:0168-ssoar-55665-7 (accessed on 4 February 2021).

114. Song, J.; Zheng, J. The Application of Grey-TOPSIS Method on Teaching Quality Evaluation of the Higher Education. Int. J. Emerg. Technol. Learn. 2015, 10, 391-397. Available online: https://online-journals.org/index.php/i-jet/article/view/5219 (accessed on 4 February 2021). [CrossRef]

115. Tiwari, A.; Mishra, N. Sustainable and smart city project: An overview of the application of multiple criteria decision making techniques and approaches for Indian context. Int. J. Manag. Appl. Sci. 2017, 3, 1-6.

116. Kılıç, M.; Taşan, S. Performance evaluation in sustainability conscious manufacturing companies by using TOPSIS method. In Proceedings of the 19th Advances in Production Management Systems (APMS), Rhodes, Greece, 24-26 September 2012.

117. Behzadian, M.; Otaghsara, S.K.; Yazdani, M.; Ignatius, J. A state-of the-art survey of TOPSIS applications. Expert Syst. Appl. 2012, 39, 13051-13069. [CrossRef]

118. Sompolska-Rzechuła, A. The Measurement and Assessment of the Quality of Life in the Region; University Publishing House of the West Pomeranian University of Technology in Szczecin: Szczecin, Poland, 2018.

119. Kendall, M.G. Rank Correlation Methods; Charles Griffin \& Company Limited: London, UK, 1948.

120. Pradhan, P. Antagonists to meeting the 2030 Agenda. Nat. Sustain. 2019, 2, 171-172. [CrossRef]

121. Nilsson, M.; Griggs, D.; Visbeck, M. Policy: Map the interactions between Sustainable Development Goals. Nat. Cell Biol. 2016, 534, 320-322. [CrossRef] [PubMed]

122. Sweden's Work on Global Health-Implementing the 2030 Agenda, Government Offices of Sweden. Available online: https: / / www.government.se/4a783f/contentassets / dd593d842fa445d29bf000bf8d97ed3e/swedens-work-on-global-health-implementing-the-2030-agenda.pdf (accessed on 22 March 2021). 